\title{
Port Logistics Policies Evaluation Based on Difference-in-Difference Model
}

\author{
Husong Xing ${ }^{1}$, Zhehui Zhang ${ }^{1}$, Yuanhui Deng ${ }^{2}$ \\ ${ }^{1}$ China Waterbome Transport Research Institute Beijing, China \\ ${ }^{2}$ National Academy of Innovation Strategy CAST Beijing, China
}

\begin{abstract}
In order to study port logistics policies' impact on related entities of port logistics, this paper try to use difference-in-difference model (DID model) in port logistics policy evaluation. Reviews related port logistics policies announced recent years in China, evaluates the policies impact on public port enterprises, and demonstrates the feasibility of using DID model to evaluate the port logistics policies. Based on whether a public port enterprises develop port logistics business, defines the public port enterprises which develop port logistics business as the experimental group, others as the control group, and establishes DID model and evaluates the policy influence. Evaluation results show that the port logistics policies have a negative impact on the gross profit of the experimental group, and DID model can be used in port logistics policies evaluation. Perhaps the strengthening of infrastructure construction, diversification and expansion of development channels enhance the operating costs of port enterprises in short-term and result in short-term earnings decline.
\end{abstract}

\section{Introduction}

During more than 30 years of Chinese Reform and Opening-up, the development of port logistics has gained great achievements. In order to accelerate the development of port logistics, a series of policies (including laws and regulations, planning, guiding opinions and demonstration projects) have been put forward to promote the development of port logistics in China, such as " Guiding opinions on accelerating the healthy development of international freight forwarders logistics industry ", "Guiding opinions on promoting port transformation and upgrading", "The medium and longterm planning for logistics industry development (20142020)", etc. As the official document of the competent government departments related made for the port logistics industry, port logistics policies could regulate and affect the behaviors of relevant port logistics organizations. The policy evaluation can let the policymakers know whether the effect of policies achieved the expected goals or promoted the target groups' development. So it is necessary to work out a scientific assessment mothed for the port logistics policies evaluation.

Therefore, this paper attempts to analyze the impact of port logistics policies on port logistics enterprises by using DID model. On the one hand, it is of great significance to explore the establishment of an objective and quantitative study tool for evaluating port logistics policies, and on the other hand, it has important guiding significance to improve the implementation of port logistics policies.

At present, many scholars have evaluated the impact of port and logistics policies on port logistics entities. Some scholars researched the impact of port management system's reform on the port operations efficiency and benefits by quantitative or qualitative research methods (mainly by qualitative method), such as Tomás Serebrisky[1] (2011), Sophia Everett[2] (2011), MC Ircha [3] (2011) and José I. Castillo-Manzano[4] (2008) studied the port reforms in Argentina, Australia, Canada and Spain by quantitative method respectively. But there were few studies on the influence of port logistics policies in China, and only a s mall number of researchers evaluated the policies impact on port logistics enterprises preliminary, such as the influences of the port law [5], port investment and financing policies[6], value-added tax policy[7], the Shanghai Free Trade Zone on[8], and lacked the impact of port logistics policies studies by quantitative methods. In terms of DID model, it has been applied to evaluate the policies impacting on fields of the med ical and health care[9], the rural tax and fee reform[10, 11], the real estate policy reform[12] and many others, since Zhou Li'an first introduced the DID method in 2005. Specifically in the field of transportation and logistics, only Wang Yao[13] (2014) and Song Xiaoli[14] (2015) used the DID model to analyze the impact of transportation infrastructure on cities. So there is no research on the port logistics policies evaluation on the real economy by the application of DID model. 


\section{Port Logistics Policies Review in China}

Although the port industry and the logistics industry have been developing for many years, it is difficult to define the accurate and high-level recognition for port logistics because it involves a large number of industries and more logistics activities of business forms. Because there is no unified definition of port logistics, there is no specific policy that can be called port logistics policy in policymaking. Therefore, this paper evaluates a series of policies for port logistics which comes from port and logistics policies. We consider the port loading and unloading and stockpiling associated inside the port area as port industry, and consider activities related to port industry outside the port area as port logistics business[15], such as dredging port transportation, warehousing, freight forward ing, customs clearance agent, logistics financial, etc. Therefore, this paper will consider the policies of dredging port transportation, warehousing, freight forwarding, customs clearance agent, logistics finance and other related to port industry businesses as port logistics policies.

Since the official document of "Planning for the logistics industry restructuring and revitalization" was announced in 2009, the logistics industry has been developed rapidly in China. There were a number of policies announced for the logistics industry development. "The guidance of transportation to promote the healthy development of the logistics industry" in 2013 clearly put forward to enhance the logistics service capabilities of the traditional transport hub, support the traditional transportation and loading-and-unloading services to extend to modern logistics services, and rely on ports, inland water ports and other port resources to enhance the international logistics service capabilities. "Gu idance on accelerating the healthy development of international freight forwarders logistics industry" in 2013 put forward to build a number of international logistics enterprises with strong competitiveness of large-scale characterized by prominent main business, advanced management mode and overseas network sound. "Guiding opinions on promoting port transformation and upgrading" in 2014 clearly put forward to develop the port logistics, support port enterprises to develop logistics real estate, supply logistics services of all-round multi-level, encourage port enterprises to extend the port logistics industry chain by diversified operation, such as cooperation with shipping, trade and other related businesses based on port industry. "The medium and long-term planning for logistics industry development (2014-2020)" in 2014 clearly put forward to promote the development of international logistics actively, strengthen infrastructure construction of the hub ports, airports, railways, highways, , form a group of international freight hub, enhance the capacity of import-and-export goods distribution, improve the facilitation level of international logistics, support the logistics enterprises joint with each other, build an international logistics service network and competitive internationally transnational logistics enterprises

The port and logistics policies mentioned above, proposed relevant policies to promote the development of port logistics, such as supporting port logistics enterprises to strengthen infrastructure construction and operate diversification, supporting international freight forwarding enterprises transformed to international largescale logistics enterprises, supporting the diversification, innovation and developing multi-level logistics services for the port enterprises, etc. These policies pointed out the development direction for the relevant port logistics enterprises, and provided opportunities and supports for the related enterprises to extend logistics businesses to some extent.

\section{Establish DID Model for Port Logistics Policy Evaluation}

\subsection{The basic principles of DID model}

The DID model has been widely used to evaluate the effect of policy or project implementation in by quantitative econometrics recent years. Usually studying a wide range of policies is different from the general scientific research, because it is difficult to guarantee completely random for distributing the samples between the experimental group and the control group. Experiments of the non-stochastic allocation between experimental group and control group can be called natural trial, which has a notable feature that there may be differences between different groups of samples before the implementation of the policy. It may ignore these differences only through a single before-andafter comparis on or lateral comparison, which will lead to biased estimates for the effects of policy implementation. DID model based on the data from natural trial can control the differences among the study objects of different group by effectively modeling, and separate the effective impact of the policy.

In the aspect of policy evaluation, the DID model can control the impact of some factors other than the intervention factors by combining the "before-and-after" and "horizontal-difference" effectively. At the same time, adding other covariates which may affect the outcome variables can further control the suspected factors between experimental group and control group, which may make up the defect of natural trial that the distribution of samples can't separate completely random. Then we could get a true policy evaluation.

There are three hypotheses needed to be fulfilled in DID model building: (1) The experimental project carried out can affect variables of the experimental group and can't affect the relevant research variables of the control group, namely the experimental project carried out can only change the relevant research variables of the experimental group; (2) During the experiment, the experimental group and the control group have the same characteristics and macro environment which has the same influence expect the control variable;(3) Some important characteristics of the experimental and control groups are stable and don't change with time, which remain stable throughout the whole experimental project.

The core of the DID model is the construction of DID estimator. By combining the simple before-after comparis on (before and after intervention) and the simple 
cross-sectional comparison (the experimental group vs. the control group), we can get the following formula:

$$
\begin{aligned}
& d=\Delta \bar{Y}_{\text {treatment }}-\Delta \bar{Y}_{\text {control }}=\left(\bar{Y}_{\text {treatment }, t_{1}}-\bar{Y}_{\text {treatment } t_{0}}\right) \\
& -\left(\bar{Y}_{\text {control } t_{1}}-\bar{Y}_{\text {control } t_{0}}\right)
\end{aligned}
$$

$d$ is the DID estimator, $Y$ is outcome variables, the subscript treatmeni and represent the experimental group and control group respectively, $t_{0}$ and $t_{1}$ represent the experiment before and after the experiment respectively.

\subsection{The applicability analysis of DID model}

The objects of port logistics policies evaluation is usually ports, logistics, shipping and other related enterprises. This paper attempts to use DID model to evaluate the impact of port logistics policies on port enterprises. According to statistics, there are 16 listed port enterprises in China. Nine of them regard the port logistics sector as a separate module, and the others don't regard the port logistics sector as a separate module when they make main business cost and income statistics. Therefore, we can divide the 16 listed port enterprises into two groups according to the listed port enterprises whether regard the port logistics sector as a separate module, one group is port enterprises engaged in port logistics business, the other group is not engaged in port logistics business. At the same time, the port enterprises are facing the same macro policy environment and the economic environ ment, and the important business indicators of the port enterprises are relatively stable. So we can make such a treatment for the port logistics policy set: the nine listed port enterprises engaged in the port logistics business can be regarded as experimental group which affected by the port logistics policy set, and the other seven port companies can be regarded as control group. We could find the port logistics policies dense announced in 2013 and 2014 according to the port logistics policies review, so we could consider it as accepted experiment after 2014, and consider it as control before 2013.

We find evaluate the impact of port logistics policy set on the operation of port enterprises quantitatively by using the DID model can basic satisfy the three basic hypotheses of the DID model building. Therefore, we can use DID model to evaluate the impact of port logistics policy set on the operation of port enterprises quantitative.

\subsection{Construct DID model for port logistics policies evaluation}

This paper selects 16 listed Chinese port enterprises as samples. Regards Lianyungang port, Rizhao port, Yantian port, Yingkou port, Shenzhen Chiwan port, Jinzhou port and Nanjing port enterprises which don't regard the port logistics sector as a separate module when they make ma in business cost and income statistics as the control group, and regards Beibu Bay port, Dalian port, Shanghai port, Xiamen port, Tangshan port, Tianjin port, Zhuhai port, Chongqing port and Ningbo port which regard the port logistics sector as a separate module when they make main business cost and income statistics as the experimental group. At the same time, make the data of 2012 as pre-test data, and make the data of 2015 as the experimental data after the port logistics policies announced. Then we could establish the port logistics policies evaluation model as follows

$$
\begin{aligned}
& Y_{i t}=b_{0}+b_{1} \bullet \text { year }_{t}+b_{2} \bullet \text { policy }_{i} \\
& +b_{3} \bullet \text { year } r_{t} \bullet \text { policy }_{i}+\theta X_{i t}+\varepsilon_{i t}
\end{aligned}
$$

In formula (2), $Y_{i t}$ is the dependent variable, yeart and policy $_{i}$ are dummy variables representing the time and the group respectively, namely the variable year for 2012 is 0 , the variable year for 2015 is 1 . The variable policy of the experimental group is 1 , while the control group is 0 . yeart policy $_{i}$ is the interaction of dummy variables of time and group. This paper selects gross profit of the 16 listed port enterprise as the dependent variable. At the same time, in order to better explain the dependent variable, the paper also introduces some control variables, including total assets and net assets of the port enterprise, total import-and-export volume of the port city, port throughput, fixed assets of whole society in the port city. Therefore, introduce the vector $X_{i t}$ as the combination of these control variables, make $\theta$ as the coefficient vector come from the regression of the control variables. $\varepsilon_{i t}$ is the residual, subscript $i$ represents each individual, subscript $t$ represents different time points.

According to the basic principles of DID model, policy $y_{i}=0$ when the port belonging to the control group, the mathematical expectation of time effect before and after the introduction of port logistics policies announced as follows.

$$
\begin{aligned}
& E\left(Y_{\text {polic } y=0, \text { year }=1}\right)-E\left(Y_{\text {policy }=0, \text { year }=0}\right)=b_{1} \\
& \text { policy } y_{i}=1 \text { when the port belonging to the }
\end{aligned}
$$
experimental group, the mathematical expectation of time effect before and after the introduction of port logistics policies announced as follows.

$$
E\left(Y_{\text {policy }=1, \text { year }=1}\right)-E\left(Y_{\text {policy }=1, \text { year }=0}\right)=b_{1}+b_{3}
$$

Therefore, the policy effect of port logistics policies is as follow.

$$
\begin{aligned}
& d=\left[E\left(Y_{\text {policy } y, 1 \text { year }=1}\right)-E\left(Y_{\text {polic } y=1, \text { year }=0}\right)\right] \\
& -\left[E\left(Y_{\text {policy }=0, \text { year }=1}\right)-E\left(Y_{\text {polic } y=0, \text { year }=0}\right)\right]=b_{3}
\end{aligned}
$$

\section{Empirical analysis of The Port Logistics Policies Effect}

\subsection{The results of Port logistics policy evaluation}

This article selects total assets and net assets of the port enterprise (TAP and NAP), total import and export volume of the port city (IEVPC), port throughput (PT), fixed assets of whole society in the port city (FASPC) as the independent variables, selects gross profit of the port enterprise (GPPE) as the dependent variable, and then analyzes the port logistics policy set impact on the gross profit of the port logistics enterprise. Related data could 
gained from the Statistical Communique on Social and Economic Development of the Port City and Annual Report of Listed Port Enterprises. Using DID model established above for port logistics policies evaluation, we can calculate and obtain the results as shown in Table 1.

Table 1. Results of DID model for port logistics policies evaluation

\begin{tabular}{cccc}
\hline & \multicolumn{3}{c}{ Dependent Variable: Gross Profit of Port } \\
Enterprise \\
\cline { 2 - 4 } Variable & Coefficient & T-value & P-value \\
\hline Policy & 6.655379 & 1.76 & 0.092 \\
Year & -6.45891 & -1.74 & 0.095 \\
Policy $\times$ & -9.055916 & -1.82 & 0.082 \\
year & -0.0698608 & -1.73 & 0.098 \\
TAP & 0.2466289 & 3.76 & 0.001 \\
NAP & 0.0026239 & 1.95 & 0.064 \\
IEVPC & 2.851475 & 2.02 & 0.055 \\
PT & 0.0011856 & 2.7 & 0.013 \\
FASPC & -6.453745 & -1.98 & 0.059 \\
c & & 0.945 & \\
R $^{2}$ & &
\end{tabular}

In table 1 , we can see that the relevant parameters passed the T-test and F-test, which indicates that the results of regression model has robustness and significates. Among them, the parameter policy $\times$ year characterized the policy effect has a value of -9.055916 , which shows that the port logistics policy has a negative impact on the gross profit of port enterprises of the experimental group which carry out port logistics business and regard the port logistics sector as a separate module.

\subsection{Analysis of the evaluation results}

According to port logistics policies review above, we can see that supporting port logistics enterprises to strengthen infrastructure construction and operate diversification, supporting international freight forwarding enterprises transformed to international large-scale logistics enterprises, supporting the diversification, innovation and developing multi-level logistics services for the port enterprises are the main port logistics policies and measures carried out in China. These policies and measures will greatly increase port enterprises investment in a short time. For example, in order to build inland dry ports, port logistics enterprises should expend a lot of money on infrastructure construction. In order to start a new business and manage diversified, the port logistics enterprises need expend a lot of money on market development and training costs, which may have an adverse impact the short-term profit of port logistics enterprises. Meanwhile, the port logistics policy announced mainly puts forward the development direction of port logistics enterprises, and don't have corresponding solutions for the development cost and the existing problems, which the port logistics enterprises have to bear alone. Those could cause cost increase and earnings decline in the development of the port logistics enterprises.

\section{Conclusions}

This paper introduces the DID model into the port logistics policies evaluation, and establish port logistics policies evaluation model for the object of port enterprises. In the empirical case, we set 2013 and 2014 as period of policies action, set 2012 as pre-experiment and 2015 as after the experiment, and then evaluate. Because promoting infrastructure ability, diversifying business, expanding the development channels will increase the burden of enterprises in the short term, the results show that the port logistics policy set have a negative impact on gross profit of the port enterprises which develop the port logistics business and regard the port logistics sector as a separate module, the results are credible. We can't have the longterm evaluation results because the implementation of the policy is relatively short, the long-term impact on port enterprises remains to be studied, but it is proved that DID model can be used in port logistics policies evaluation.

\section{References}

1. Tomás Serebrisky. "An assessment of port reform in Argentina: outcomes and challenges ahead", Maritime Policy \& Management, vol. 32, 2011, pp.191-207.

2. Sophia Everett. "Port reform in Australia issues in the ownership debate", Maritime Policy \& Management, vol. 34, 2011, pp.107-119.

3. M. C. Ircha. "Port strategic planning: Canadian port reform", Maritime Policy \& Management, vol. 34, 2011, pp.125-140.

4. José I. Castillo-Manzano. "Economic analysis of the Spanish port sector reform during the 1990s", Transportation Research Part A, vol. 42, 2008, pp.1056-1063.

5. ZHANG G J. "Study on the impact of port law on corporation performance of Guangzhou port group", Southwest Jiaotong University, 2003.

6. LI Y N. "Evaluation on the port investment and financing policy", Shanghai Maritime University, 2007.

7. GUO Y P. "The influence of value-added tax policy transformation on logistics enterprise", Shang Ye Jing Ji, vol. 5, 2009, pp.109-110.

8. FU X. "Research of China(Shanghai) Pilot Free Trade Zone's significance of transforming , development and value of port logistics corporate", Shanghai Jiao Tong University, 2014.

9. Torche F. "The effect of maternal stress on birth outcomes: exploiting a natural experiment " Demography, 2011.

10. ZHOU L A, CHEN Y. "The policy effect of tax-andfees reforms in rural China: a Difference-inDifferences estimation", Economic Research Journal, vol. 8, 2005, pp.44-53.

11. WANG W, AI CH R, CAO H. "Research the tax and fee reform influence on the rural residents' consumption", Management World(Monthly), vol. 1,2013, pp.89-100. 
12. LIU J Y. "The evaluation of reform of property tag and effect on the household saving", Huazhong University of Science\& Technology, 2014.

13. WANG Y, NIAN M. "High speed railway and urban scale expansion - based on empirical research of China", Finance \& Economics , vol. 10, 2014, pp.113-122.
14. SONG X L, LI K W. "The effects of improving the quality of traffic infrastructure on urban population scale-An empirical analysis based-on railway speedup", Modern Economic Science, vol. 5, 2015, pp.19-26.

15. XING H S, ZHANG ZH H. "The effect of developing port logistics on the port industry", Shipping Management, vol. 3, 2015, pp.14-17. 